\title{
Optimal Production of $\beta$-Galactosidase from Lactobacillus fermentum for the Synthesis of Prebiotic Galactooligosaccharides (GOS)
}

\author{
Shilpa Mahadevaiah, Renuka Basavaiah, Manmohan Parida and \\ Harsh Vardhan Batra* (iD \\ Microbiology Division, Defence Food Research Laboratory, DRDO, Mysore - 570 011, Karnataka, India.
}

\begin{abstract}
The enzyme $\beta$-galactosidase ( $\beta$-gal) has extensively used for improvement of lactose intolerance condition. Present study, was designed to assess the potential of $\beta$-gal enzyme produced by Lactobacillus fermentum, a kefir isolate, as a biocatalyst for the manufacture of prebiotic galactooligosaccharides (GOS) from lactose. The efficiency of $L$. fermentum to produce $\beta$-gal of $4,254 \mathrm{u} / \mathrm{ml}$ was determined by permeabilizing the cells with solvents such as sodium dodecyl sulfate (SDS) and chloroform. Different parameters contributing $\beta$-gal production including reaction time, temperature, $\mathrm{pH}$, carbohydrates, and substrate concentration on $L$. fermentum were studied and optimum $\beta$-gal activity was found to be $6,232.13 \mathrm{u} / \mathrm{ml}$. It was observed that different experimental parameters for $\mathrm{pH}(7.0)$, temperature $\left(35^{\circ} \mathrm{C}\right)$, and carbohydrates (galactose) were statistically significant $(p<0.05)$. L. fermentum was found to produce GOS by transgalactosylation catalysed by $\beta$-gal during lactose hydrolysis which yielded di, tri, and tetra oligosaccharides, confirmed by TLC and HPLC. The culture showed $\beta$-gal activity, suggesting biotechnological applications and a promising organism for industrial $\beta$-gal production.
\end{abstract}

Keywords: $\beta$-galactosidase, galactooligosaccharides, Lactobacillus fermentum, ONPG, prebiotics

*Correspondence: drharshvardanbatra@gmail.com; +91-9342054402

(Received: July 17, 2020; accepted: October 16, 2020)

Abbreviations: GOS- Galactooligosaccharides, ONPG - Ortho-Nitrophenyl- $\beta$-galactoside, GRAS - Generally regarded as safe, YEPD- Yeast Extract Peptone Dextrose, PDA- Potato dextrose agar, MRS- De-Man Rogosa Sharpe, X-gal- 5-bromo-4-chloro3-indolyl- $\beta$-D-galactopyranoside, IPTG- isopropyl $\beta$-D-1-thiogalactopyranoside, DMSO- dimethyl sulphoxide, SDS- sodium dodecyl sulphate, LAB-Lactic acid bacteria.

Citation: Mahadevaiah S, Basavaiah R, Parida M, Batra HV. Optimal Production of B-Galactosidase from Lactobacillus fermentum for the Synthesis of Prebiotic Galactooligosaccharides (Gos). J Pure Appl Microbiol. 2020;14(4):2769-2780. doi: 10.22207/ JPAM.14.4.53

(C) The Author(s) 2020. Open Access. This article is distributed under the terms of the Creative Commons Attribution 4.0 International License which permits unrestricted use, sharing, distribution, and reproduction in any medium, provided you give appropriate credit to the original author(s) and the source, provide a link to the Creative Commons license, and indicate if changes were made. 


\section{INTRODUCTION}

"A prebiotic is defined as a substrate that is selectively utilized by host microorganisms conferring health benefit" as stated by Gibson et al., in Expert Consensus document in International Scientific Association for Probiotics and Prebiotics (Gibson et al., 2017). Prebiotics of interest includes fructo-oligosaccharides (FOS), galactooligosaccharides (GOS), inulin, xylooligosaccharides (XOS), polydextose, isomaltooligosaccharides (IMO), manno-oligosaccharides (MOS), lactulose and arabinoxylo-oligosaccharides (AXOS) (Slavin, 2013; Davani-Davari et al., 2019). Among these, GOS are prominent hetero-oligosaccharides containing galactose, a oligosaccharides resembling milk of human breast (Intanon et al., 2014; Sangwan et al., 2011) which has greater stablility and has wide $\mathrm{pH}$ and temperature range (Torres et al., 2010). GOS enhances the growth of bifidobacteria and lactobacilli in the gut thus provide benefits to health. GOS has a low calorific value of about $1.7 \mathrm{k} \mathrm{cal} / \mathrm{g}$ and can be synthesized using lactose as substrate in the presence of $\beta$-galactosidase ( $\beta$-gal) enzyme. $\beta$-gal also known as lactases, are of industrial importance. They are produced by a number of sources including microorganisms, plants, animals, vegetables and recombinant sources (Hirano et al., 1994; Raymond R. Mahoney, 1998; Chen et al., 2008; Li et al., 2012).

Microorganisms are considered as suitable source for $\beta$-gal production in industries because of its high multiplication rate, yield and stability. $\beta$-gal producing lactic acid bacteria (LAB) including L. plantarum MCC2156, L. reuteri L103 and L461, L. acidophilus R22, L. thermophilus, L. crispatus ATCC 33820, and L. delbrueckii spp. bulgaricus ATCC 11842 were reported (Gobinath and Prapulla, 2014; Kim and Rajagopal, 2000; Nguyen et al., 2006; Nguyen et al., 2007) and are predominantly present in brush border of small intestine. Gobinath et al., previously reported production of $\beta$-gal by $L$. plantarum up to 3,015 $\mathrm{u} / \mathrm{ml}$ (Gobinath and Prapulla, 2014).

$\beta$-gal displays both hydrolytic and transgalactosylation activity (Guerrero et al., 2015). In hydrolysis, $\beta(1 \rightarrow 4)$ glycosidic linkage of lactose (galactosyl $\beta$ - $(1 \rightarrow 4)$ glucose) is splited into its monosaccharides i.e., glucose and galactose, whereas in transgalactosylation, galactose is transferred to lactose rather than transferring to its hydroxyl group to form di, tri or tetra saccharides and hence form higher degree of polymerization (Panesar et al., 2007).

The $\beta$-gal has main industrial application in the hydrolysis of lactose to improve milk digestibility and to enhance the functional properties of dairy products (Gekas et al., 1985). In dairy industry, hydrolysed milk obtained can be used in making of yoghurt, cheese and ice cream (concentrated desserts) for lactose intolerant subjects. (Marwaha and Kennedy, 2007).

The present study is based on the reports on optimization of $\beta$-gal production from Lactobacillus fermentum from kefir for the synthesis of prebiotic galactooligosaccharide. GOS are one of the important dietary prebiotics (Goulas et al., 2007) which has GRAS status and promote beneficial effects on microflora.

\section{MATERIALS AND METHODS \\ Chemicals used}

MRS medium, lactose, glucose, galactose, ONPG and lysozyme-EDTA were procured from HiMedia. X-gal, IPTG, DMSO and GOS from SigmaAldrich (St. Louis, MO, USA). Other solvents such as isoamyl alcohol, SDS, chloroform, glycerol, toluene, acetone and acetonitrile are of analytical grade.

Screening of microbes for $\beta$-gal enzyme production

In the present study, 107 microbes including $L A B$, yeast and fungi were screened from kefir and cotton seed cake by submerged and solid state fermentation respectively. LAB were grown on MRS broth at $37^{\circ} \mathrm{C}$, yeasts were grown on YEPD broth at $37^{\circ} \mathrm{C}$ for $24-48 \mathrm{hrs}$ and all fungal cultures were grown on PDA at $30^{\circ} \mathrm{C}$ for 5 to 7 days. Further for screening of microbes producing $\beta$-gal, a colourless modified galactose sugar $X$-gal was used. The cultures were examined after 12 to 24 hrs of incubation at $37^{\circ} \mathrm{C}$ and at $30^{\circ} \mathrm{C}$ respectively.

Morphological, biochemical and molecular characterization of $\beta$-gal producing strains were performed. Morphological was studied by simple gram staining. Biochemical tests including catalase test and fermentation tests for glucose, galactose, lactose, maltose, and sucrose at a concentration of $2 \%$ in modified MRS broth (weighed and mixed each ingredient of MRS media) at $37^{\circ} \mathrm{C}$ was performed. 
$\beta$-galactosidase extraction by different methods

Different methods for cell disruption was carried out including sonication, lysozymeEDTA treatment, isoamyl alcohol treatment, toluene-acetone treatment, toluene treatment and sodium dodecyl sulphate (SDS)-chloroform treatment were applied to appraise and estimate the effectiveness of the different methods to find suitable method to obtain $\beta$-gal.

\section{Harvesting of cell biomass}

After $15 \mathrm{hr}$ of incubation, culture pellet was washed twice to remove media components with $50 \mathrm{M}$ sodium phosphate buffer $(\mathrm{pH} 7.0)$ and transferred to $50 \mathrm{M}$ phosphate buffer $(\mathrm{pH} 6.8)$ for extraction of intracellular enzyme and different methods are listed below.

\section{Sonication}

In an ice bath, cell suspensions were sonicated for $30 \mathrm{~min}$ in an ultra sonicator (UP200H ultra sonic processor, Hielscher) according to previously described method (Becerra et al., 1997). The extract was centrifuged at $10,000 \times \mathrm{g}$ at $4^{\circ} \mathrm{C}$ for 10 min with $15 \%$ amplitude and with intermittent cooling in 5 cycles and the supernatant containing the crude enzyme extract was stored at $-20^{\circ} \mathrm{C}$.

\section{Lysozyme-EDTA treatment}

$50 \mathrm{mg}$ of lysozyme was dissolved in 1.5 $\mathrm{ml}$ of TE (Tris-EDTA; Ethylenediamine Tetraacetic Acid) buffer containing $10 \mathrm{mM}$ Tris $\mathrm{HCl}$ and $1 \mathrm{mM}$ EDTA by adjusting the $\mathrm{pH}$ to 8 . At a concentration of $75 \mu \mathrm{l} / \mathrm{ml}$ of the preparation was added to the cell suspension and the mixture was incubated for $30 \mathrm{~min}$ at ambient temperature and stored at $-20^{\circ} \mathrm{C}$ until further analysis (Prasad et al., 2012).

\section{Isoamyl alcohol treatment}

A volume of $1 \mathrm{ml}$ was re-suspended in sodium phosphate buffer of $50 \mathrm{mM}$ at pH 7.0 and $2 \mathrm{ml}$ of isoamyl alcohol was mixed and was diluted using the same buffer. The cell suspension was shaken at ambient temperature to permeabilize the cells and assay was carried out according to Barberis with slight modifications (Barberis and Gentina, 1998).

\section{Toluene-acetone treatment}

Cell suspension $(10 \mathrm{ml})$ was crushed in pestle and mortar for 10 min along with $2.0 \mathrm{~g}$ alumina and acetone and toluene was mixed in the ratio 9:1. Phosphate buffer was added to the suspension and after centrifugation at 10,000×g for $15 \mathrm{~min}$, supernatant was used for enzyme assay (Mahoney et al., 1975).

\section{Toluene}

Cold toluene was mixed with equal volume of $1 \mathrm{ml}$ cell suspension and stirred continuously for $15 \mathrm{~min}$ and mixed well for 5 min and supernatant was stored at $-20^{\circ} \mathrm{C}$ after centrifugation for 15 min until further assay (Gupte et al., 2001).

\section{SDS-Chloroform method}

Permeabilization was carried out according to miller's method with slight modification to permeabilize the cells. Cell suspension $(10 \mathrm{ml})$ was vortexed with $50 \mu \mathrm{l}$ chloroform and SDS solution for $15 \mathrm{~min}$ at ambient temperature. The cell suspension was centrifuged for $15 \mathrm{~min}$ at $4^{\circ} \mathrm{C}$ at $10,000 \times \mathrm{g}$ and supernatant was used to determine enzyme activity (Gobinath et al., 2014).

Determination of enzyme activity

Miller's method (1972) was used to determine the enzyme production with slight modifications by increasing the concentration of SDS and chloroform (Miller, 1972). $1 \mathrm{ml}$ culture broth was harvested at $10,000 \times \mathrm{g}$, for $10 \mathrm{~min}$ and 50 $\mathrm{mM}$ sodium phosphate buffer ( $\mathrm{pH} 7.0$ ) was used to wash the cells and transferred to $Z$ buffer $(60 \mathrm{mM}$ $\mathrm{Na}_{2} \mathrm{HPO}_{4} \cdot 7 \mathrm{H}_{2} \mathrm{O}, 40 \mathrm{mM} \mathrm{NaH} \mathrm{PO}_{4} \cdot \mathrm{H}_{2} \mathrm{O}, 10 \mathrm{mM} \mathrm{KCl}$, $1 \mathrm{mM} \mathrm{MgSO}{ }_{4} \cdot 7 \mathrm{H}_{2} \mathrm{O}, 50 \mathrm{mM} \beta$-mercaptoethanol) and initial cell concentration was measured at absorbance $\left(\mathrm{A}_{600}\right)$. Cell permeabilization was carried out using SDS and chloroform in the ratio 50:50 $\mu \mathrm{l}$ and mixed thoroughly (IKA Vortex, IKA, Germany) for $15 \mathrm{~min}$ at $37^{\circ} \mathrm{C}$. Enzyme activity was measured using $10 \mathrm{mM}$ of ONPG to the reaction mixture and incubated at $37^{\circ} \mathrm{C}$ for 10 min. Absorbance $\left(A_{420}\right)$ and $\left(A_{560}\right)$ were recorded after arresting the reaction by adding $0.5 \mathrm{ml}$ of 1 $\mathrm{M} \mathrm{Na}_{2} \mathrm{CO}_{3}$. Miller units was calculated according to the formula:

Miller Unit $=1000 \times\left(A_{420}-\left(1: 75 * A_{560}\right) / T * V * A_{600}\right.$ $\left[A_{600} \mathrm{~nm}\right.$ - Absorbance of cells before assay; $A_{560}$ - Absorbance of scatter from cell debris, when multiplied by 1.75 approximates the scatter observed at $420 \mathrm{~nm}$, after assay; A420Absorbance of o-nitrophenol (ONP) released; $T$ = time of the reaction ( $\mathrm{min}) ; \mathrm{v}=$ volume of original culture used (ml)]. L. fermentum MT468249 was further used for GOS production. 


\section{Protein determination}

Lowry's method was used to determine the protein content using bovine serum albumin (BSA) as standard. The samples were read at $575 \mathrm{~nm}$ using a double beam UV - visible spectrophotometer (SL164 Elico, Hyderabad, India). The protein concentration was estimated in triplicates.

Parameters affecting Miller assay on L. fermentum MT468249 for $\beta$-gal production

\section{Effect of permeabilizing agents}

Miller's original protocol was modified for $\beta$-gal assay using solvents such as SDS and chloroform in varying amounts. $15 \mathrm{hr}$ old culture was taken and SDS-chloroform was added in different concentrations (Giacomini et al., 1992) such as 10:40, 50:50, 100:100 and 150:150 and assay was carried out as mentioned above using ONPG as substrate.

\section{Reaction time}

Reaction time plays an important role in $\beta$-gal enzymatic activity. Different incubation time was studied for $\beta$-gal activity (Gobinath et al., 2014), enzyme was incubated (2, 5 and $10 \mathrm{~min}$ ) and Miller assay was carried out as mentioned above.

\section{ONPG concentration}

Multiple concentrations of ONPG such as $4 \mathrm{mg} / \mathrm{ml}, 10 \mathrm{mg} / \mathrm{ml}$ and $20 \mathrm{mg} / \mathrm{ml}$ were used to find out the maximum $\beta$-gal activity and Miller assay was carried out as mentioned above.

Effect of medium $\mathrm{pH}$, incubation temperature, and different carbon sources on $L$. fermentum MT468249 for $\beta$-gal production

Effect of initial $\mathrm{pH}$

Culture medium was adjusted with different initial $\mathrm{pH}$ values to examine for intracellular $\beta$-gal extracted by six different methods. Medium was incubated with different $\mathrm{pH}$

Table 1. Different extraction methods of potential isolates and their $\beta$-gal activity. Milk kefir in milk isolates (MKM), Milk isolates (M), and Curd isolates (C)

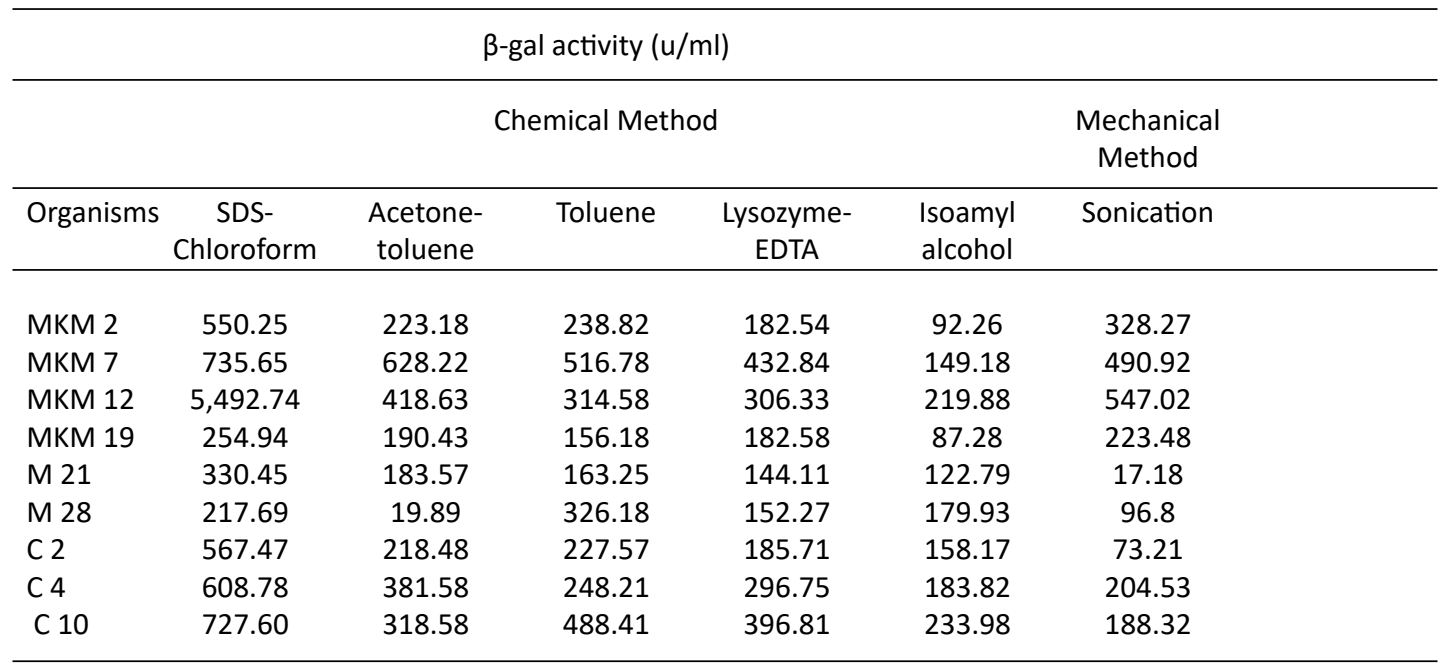

Table 2. Permeabilizing agent used and its enzyme activity

\begin{tabular}{ll}
\hline $\begin{array}{l}\text { Different ratio } \\
\text { (SDS: chloroform [v/v]) }\end{array}$ & $\begin{array}{l}\text { Units/ml } \\
(15 \mathrm{hrs})\end{array}$ \\
\hline $10: 40$ & $1,203.29$ \\
$50: 50$ & $5,021.13$ \\
$100: 100$ & $2,427.14$ \\
$150: 150$ & $2,157.71$ \\
\hline
\end{tabular}

from 5.0, 5.5, 6.0, 6.5, 7.0, 7.5 and 8.0 using either $2 \mathrm{~N} \mathrm{NaOH}$ or $3 \mathrm{~N} \mathrm{HCl}$ for 15 hrs at $37^{\circ} \mathrm{C}$ (Murad et al., 2011, Hsu et al., 2005).

\section{Effect of incubation temperature}

Different temperature studies were carried out on media for $\beta$-gal production by incubating $L$. fermentum at various temperatures ranging from 30 to $50^{\circ} \mathrm{C}$ for $15 \mathrm{hrs}$ at $\mathrm{pH} 7.0$ (Gobinath et al., 2014) 


\section{Carbon sources}

Different carbon sources containing $2 \%(\mathrm{w} / \mathrm{v})$ glucose, galactose, lactose, maltose and sucrose were used to grow $L$. fermentum in modified MRS medium at $37^{\circ} \mathrm{C}$ for $15 \mathrm{hrs}$ (Gobinath et al., 2014).

\section{Synthesis of GOS}

Synthesis of GOS was carrying out with 5 to $60 \%$ of lactose $(w / v)$, at various $\mathrm{pH}$ values $(5-8)$ and temperatures $\left(30-60^{\circ} \mathrm{C}\right)$ with $9 \mathrm{U}$ of enzyme $\mathrm{ml}^{-1}$ for $15-24 \mathrm{hrs}$. Samples were withdrawn each hour and the substrate enzyme reaction was stopped by boiling the mixture in a boiling water bath for $10 \mathrm{~min}$ and stored at $-20^{\circ} \mathrm{C}$ till further analysis.

\section{Thin layer chromatography (TLC)}

Qualitative analyses of GOS were carried out using TLC with three solvents using butanolacetic acid-water $(8: 4: 4[\mathrm{v} / \mathrm{v} / \mathrm{v}])$ as the mobile phase. Spots were detected by spraying $19 \%$ methanol in concentrated sulphuric acid and

Table 3. Effect of reaction time on enzyme activity by L. fermentum

\begin{tabular}{ll}
\hline $\begin{array}{l}\text { Time } \\
(\min )\end{array}$ & $\begin{array}{c}\text { Miller units } \\
\text { (units/ml) }\end{array}$ \\
\hline 1 & $2,809.06$ \\
2 & $5,601.13$ \\
5 & $4,124.57$ \\
10 & $3,045.15$ \\
\hline
\end{tabular}

incubated in an oven for $10 \mathrm{~min}$ at $120^{\circ} \mathrm{C}$ (Dafam et al., 2014).

High performance liquid chromatography (HPLC) Detection of GOS (Jeong et al., 1998) was quantitatively carried out using carbohydrate column $(250 \mathrm{~mm} \times 4.6 \mathrm{~mm}$ SS Excil amino $5 \mu \mathrm{m}$ (Santa Clara, California) with refractive index detector (RID 20A) (Agilent technologies 1260 Infinity) and isocratic elution using acetonitrile/ water (75: 25) as the mobile phase at a flow rate of $1.2 \mathrm{ml} / \mathrm{min}$ (Ayyappan et al., 2008). Oligosaccharides were diluted and filtered through a cellulose nitrate membrane $(0.45 \mu \mathrm{m})$ and $15 \mu \mathrm{l}$ of hydrolysate was injected through HPLC injector syringe. The reaction mixture products were identified by comparing the retention times with those of the standards.

\section{Statistical analysis}

All experiments were performed in triplicates. The data analyses were performed using Graph pad prism version 5.03. ANOVA data

Table 4. Effect of ONPG concentration on enzyme activity by $L$. fermentum

\begin{tabular}{ll}
\hline $\begin{array}{l}\text { ONPG concen. } \\
(\mathrm{mg} / \mathrm{ml})\end{array}$ & $\begin{array}{l}\text { Miller units } \\
\text { (units/ml) }\end{array}$ \\
\hline 4 & $1,248.45$ \\
10 & $5,801.13$ \\
15 & $4,526.84$ \\
20 & $3,122.08$ \\
\hline
\end{tabular}

\section{pH vs Enzyme activity}

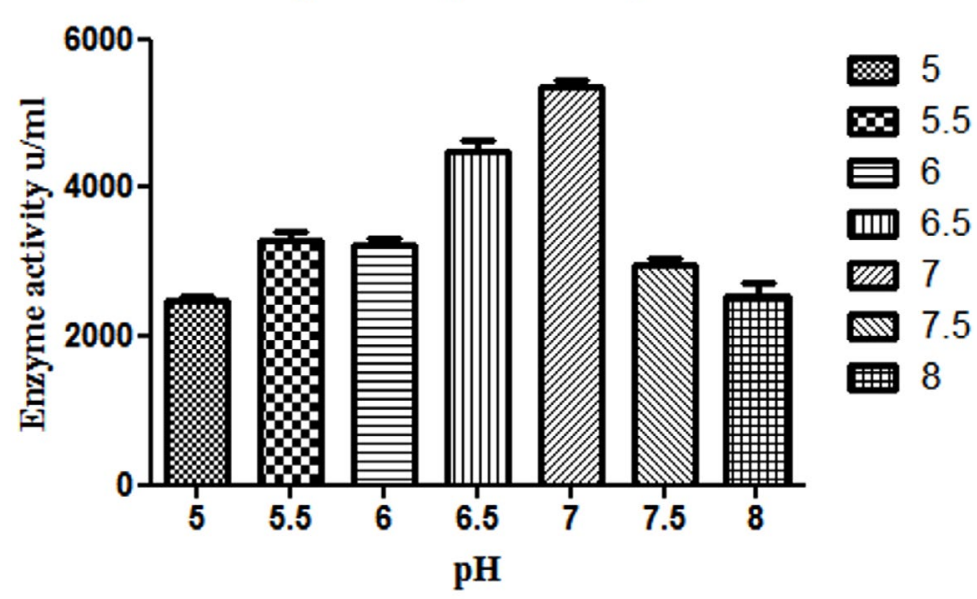

Fig. 1. Effect of different $\mathrm{pH}$ on $\beta$-gal production by L. fermentum. Bars show standard deviations with significant difference $(p<0.05)$. 
with a $p<0.05$ were considered as statistically significant.

\section{RESULTS}

Screening of microbes for $\beta$-gal enzyme production Of a total of 107 isolates that were screened for $\beta$-gal production (bacteria- 79, yeast- 23 and fungi- 3), a total of 69 isolates (bacteria- 60, yeast-9) were positive, while none of the fungal isolates produced $\beta$-gal. Colonies that displayed $\beta$-gal production within 12 to $24 \mathrm{hrs}$ were selected from blue white screening method and which produced blue colonies includes nine isolates (Milk kefir in milk isolates, MKM) MKM
2, MKM 7, MKM 12, MKM 19, (Milk isolates) M 21, M 28, (Curd isolates) C 2, C 4 and C 10 (Table 1). The strain MKM 12 was gram-positive, nonmotile, rod shaped bacteria with catalase negative activity. The sequencing revealed the isolate was $L$. fermentum. The sequences were confirmed with NCBI BLAST database for identifying the culture. The sequences of Lactobacillus fermentum were deposited in NCBI-GenBank and the accession number is MT468249. In turn to assess the efficacy of the L. fermentum MT468249, bacterial growth in mid-logarithmic phase was used and plated with different dilutions $\left(10^{-5}, 10^{-6}\right.$ and $10^{-}$ ${ }^{7}$ ). The isolate showed $5,132.12 \mathrm{u} / \mathrm{ml}$ of activity

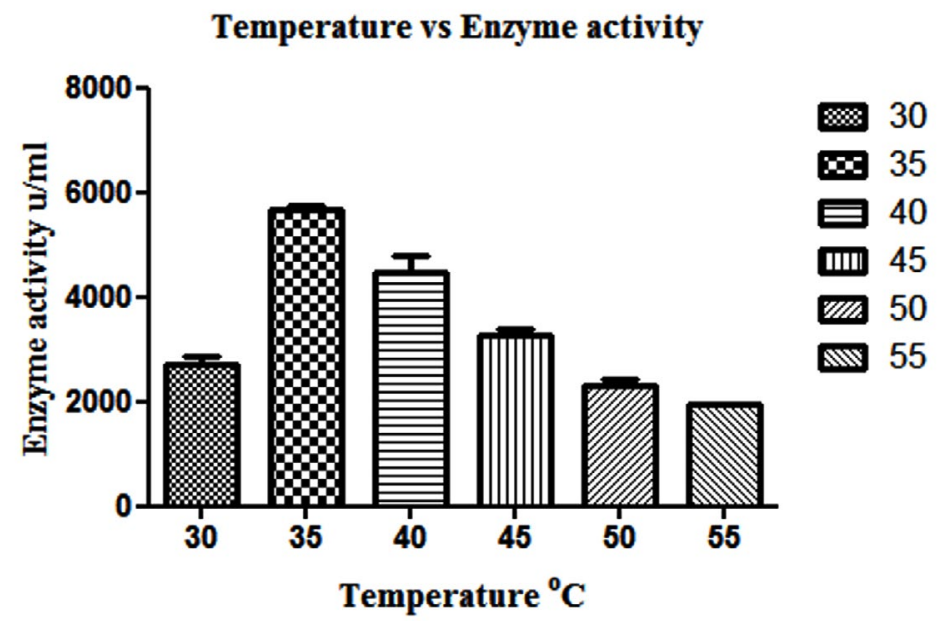

Fig. 2. Effect of different temperature on $\beta$-gal production by $L$. fermentum. Bars show standard deviations with significant difference $(p<0.05)$

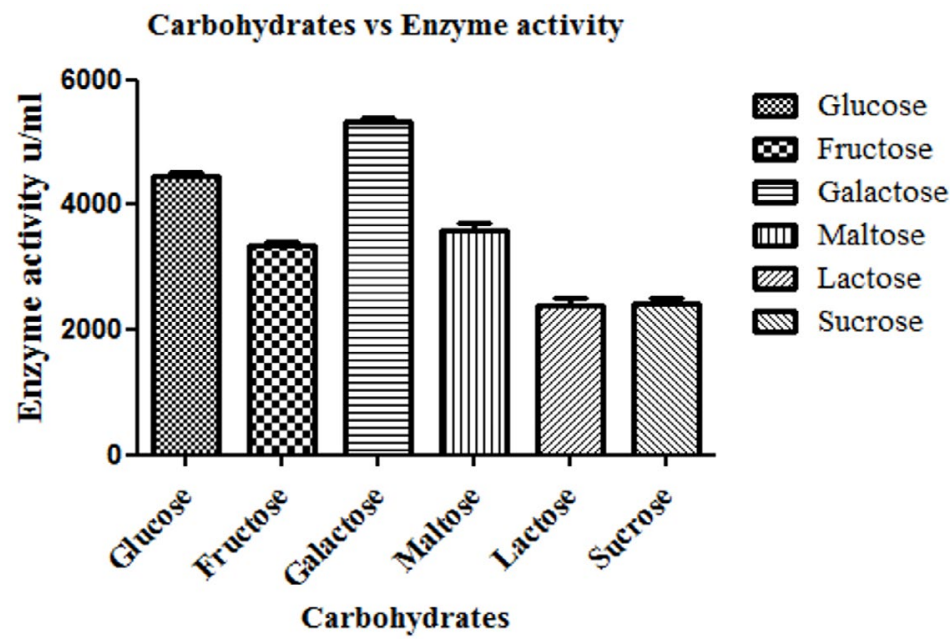

Fig. 3. Effect of different carbohydrates on $\beta$-gal production by L. fermentum. Bars show standard deviations with significant difference $(p<0.05)$. 
at $600 \mathrm{~nm}$ optical density expressed as $7.47 \mathrm{log}$ $\mathrm{CFU} / \mathrm{ml}, 8.02 \log \mathrm{CFU} / \mathrm{ml}$ and $8.0 \mathrm{log} \mathrm{CFU} / \mathrm{ml}$ of $4,987.28 \mathrm{u} / \mathrm{ml}, 5,132.127 \mathrm{u} / \mathrm{ml}$ and $5,349.15 \mathrm{u} /$ $\mathrm{ml}$ samples respectively. Till date, this is the first report showing optimum $\beta$-gal enzyme activity by L. fermentum MT468249.

\section{Extraction of $\boldsymbol{\beta}$-galactosidase}

Addition of SDS-chloroform solvents to increase the permeabilization of cells to release the enzyme was achieved using different concentrations of solvents. The results indicate progressive better enzyme extraction when the concentrations of solvents were increased up to $1: 1$ however there is a decrease in $\beta$-gal activity with increase in the concentration. Among them, $50 / 50(v / v)$ concentrations have shown maximum activity and were chosen for further study (Table 2).

\section{Parameters affecting Miller assay on L. fermentum MT468249 for $\beta$-gal production}

$\beta$-gal activity was obtained within one minute $(2,809.06 \mathrm{u} / \mathrm{ml})$ at higher $\mathrm{pH}$ when ONPG is converted to ONP and galactose. As the enzyme concentration decreases, the reaction rate will decrease. In this study, decrease in $\beta$-gal activity was observed with increasing time with $5 \mathrm{~min}$ and $10 \mathrm{~min}$, because the enzyme concentration decreases, as the reaction rate decreases (Table 3 ). The enzyme activity was highest during initial stages and decreased relative to time. There was an increase in $\beta$-gal activity within two minute $(5,601.13 \mathrm{u} / \mathrm{ml})$ and decrease in activity was observed as the time increases (within ten minutes $-3,045.15 \mathrm{u} / \mathrm{ml}$ ). Optimum concentrations of ONPG were determined based on four different concentrations. A concentration of $10 \mathrm{mg} / \mathrm{ml}$ was found to be saturating for $L$. fermentum. Further increase in concentration beyond $10 \mathrm{mg} / \mathrm{ml}$ decreased the activity (Table 4).

Production of $\beta$-gal by $L$. fermentum was studied at different $\mathrm{pH}$ 5.0, 5.5, 6.0, 6.5, 7.0, 7.5 and 8.0 for $\beta$-gal production and maximum production was found to be at $\mathrm{pH} 7.0$ (Fig. 1).

$\beta$-gal production is highest, when $L$. fermentum was grown at a temperature ranging from 30 to $45^{\circ} \mathrm{C}$ over a period of $15 \mathrm{hrs}(\mathrm{p}<0.05)$, whereas further increase in temperature above $50^{\circ} \mathrm{C}$ decreased the enzyme production (Fig. 2).

The effect of different carbon sources such as galactose, lactose, maltose and sucrose on production of $\beta$-gal enzyme by $L$. fermentum is shown in Fig. 3. Among different carbon sources used, galactose was found to produce highest $\beta$-gal $(p<0.05)$ by $L$. fermentum than lactose, glucose, sucrose, fructose and maltose. In the present study, L. fermentum produced the maximum quantity of $\beta$-gal enzyme with galactose $(5,294.07$ $\mathrm{u} / \mathrm{ml})(\mathrm{p}<0.05)$ and lowest being sucrose $(2,422.81$ $\mathrm{u} / \mathrm{ml})$.

The production of GOS, by L. fermentum was further confirmed by TLC (Fig. 4). The sample spots are identical with the standard GOS. These GOS spots are combination of di, tri and tetra saccharides confirmed by HPLC. (Fig. 6)

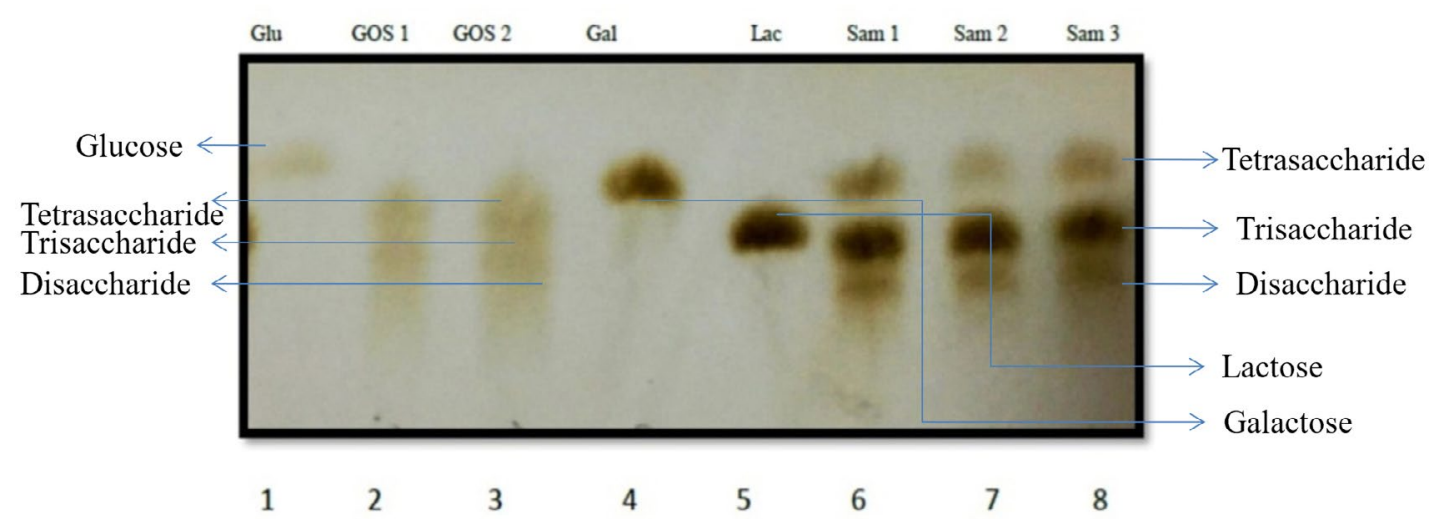

Fig. 4. Synthesis of GOS from L. fermentum with beta-gal enzymes and galactooligosaccharide mixtures are identified as follows: Line 1- Glucose; Line 2- Standard GOS (3:1); Line 3-Standard GOS (4:1); Line 4-Galactose; Line 5- Lactose; Line 6- L. fermentum (18hr), Line 7- L. fermentum (20hr); Line 8- L. fermentum (22hr). 


\section{DISCUSSION}

Disintegration of cells is considered as an efficient method used in the production of intracellular $\beta$-gal from LAB. In the present study, cell disintegration results showed that enzyme yield was dependent on different methods used. Culture bio mass was subjected to mechanical and chemical disruption methods such as sonication, SDS-chloroform, acetone-toluene treatment, toluene treatment, lysozyme-EDTA and isoamyl alcohol treatment. SDS-chloroform method (Table 1) was found to be most effective in MKM 12 compared to other methods for the discharge of intracellular $\beta$-gal from cell pellets.

Reports regarding discharge of intracellular $\beta$-gal which is bound to cell wall from biomass of LAB are meagre (Somkuti et al., 1998). Anionic detergent such as SDS causes the molecule to lose its native structure by distracting non covalent bonds in the proteins. Chloroform, is a miscible solvent with most organic solvents, which is used for permeabilization of cells. Hence the solvents have the capability of permeabilizing the cell wall of bacteria and consecutive release of intracellular $\beta$-gal enzyme (Panesar et al., 2007). The culture pellet displayed comparatively high $\beta$-gal enzyme than in supernatant (data not shown), confirming intracellular enzyme production (Song et al., 2013). Our findings are similar with previously published articles of Vinderola et al., (2003) and Gobinath et al., (2014) who found SDS-chloroform method was more effective in L. delbrueckii subsp. bulgaricus Db1, Eb3 and L. plantarum MCC2156. $\beta$-gal activity has also been reported from $L$. fermentum CM33 isolated from breast feed infants showed 0.4 $\mathrm{u} / 100 \mathrm{~mL}$ which is less compared to our study (Sriphannam et al., 2012). Out of nine cultures, the isolate MKM 12 showed efficient $\beta$-gal production in SDS-chloroform method and found to have reproducibility by producing high yield of $5,132.127 \mathrm{u} / \mathrm{ml}$.

Giacomini et al., reported a reduced amount of enzyme activity when $5 \mu$ l of SDS and $10 \mu \mathrm{l}$ of chloroform were used due to insufficient permeabilization of enzyme producing a lesser amount of enzyme activity (Giacomini et al., 1992). However, $15 \mu \mathrm{l}$ SDS and $30 \mu \mathrm{l}$ chloroform had inhibited the enzyme activity in a negative manner. Hence it was desirable to use $10 \mu \mathrm{l}$ SDS and $20 \mu \mathrm{l}$ chloroform which produced better enzymatic activity of $\beta$-gal enzyme by permeabilizing cells. Similar observations on the effect of permeabilization by adding SDS (0.1

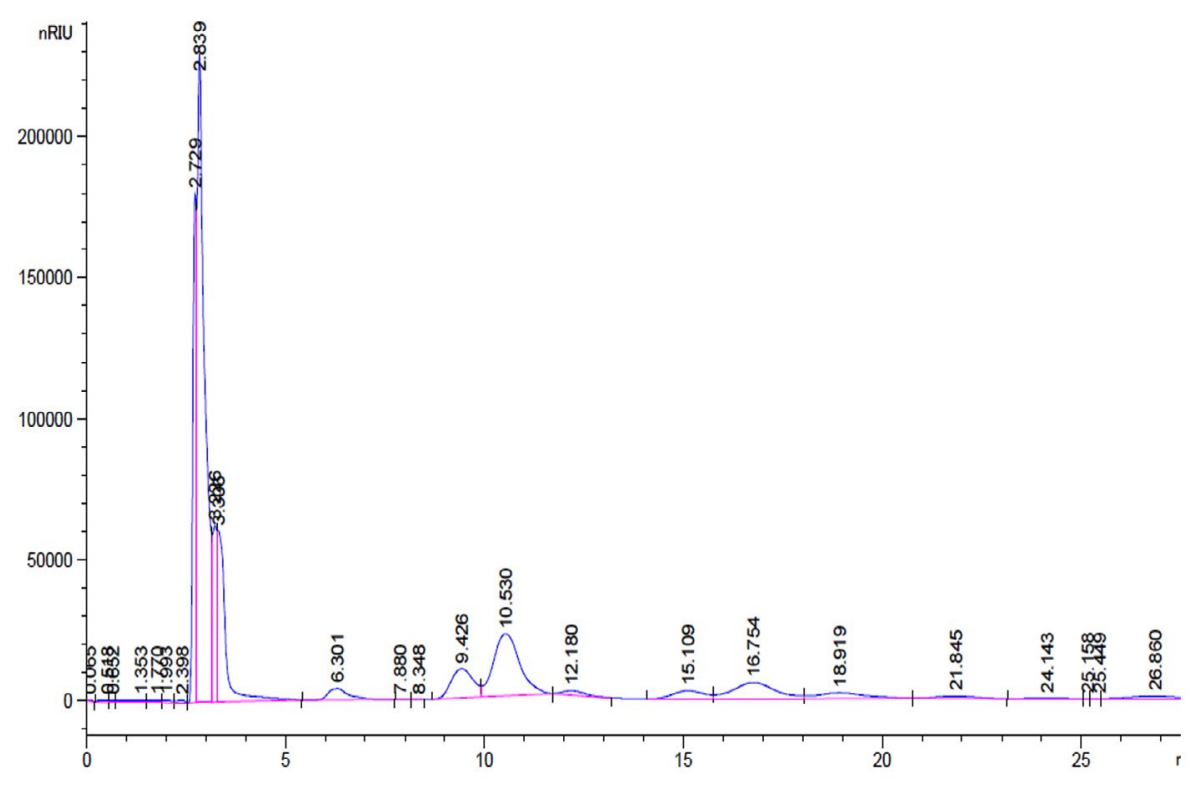

Fig. 5. Standard GOS peaks with retention factor- Galactose and Glucose 2.63, Lactose 6.36, disaccharides 10.53 and 12.18 , trisaccharides $16.75,18.91$ and tetrasaccharides 21.8 and 25.44 . 


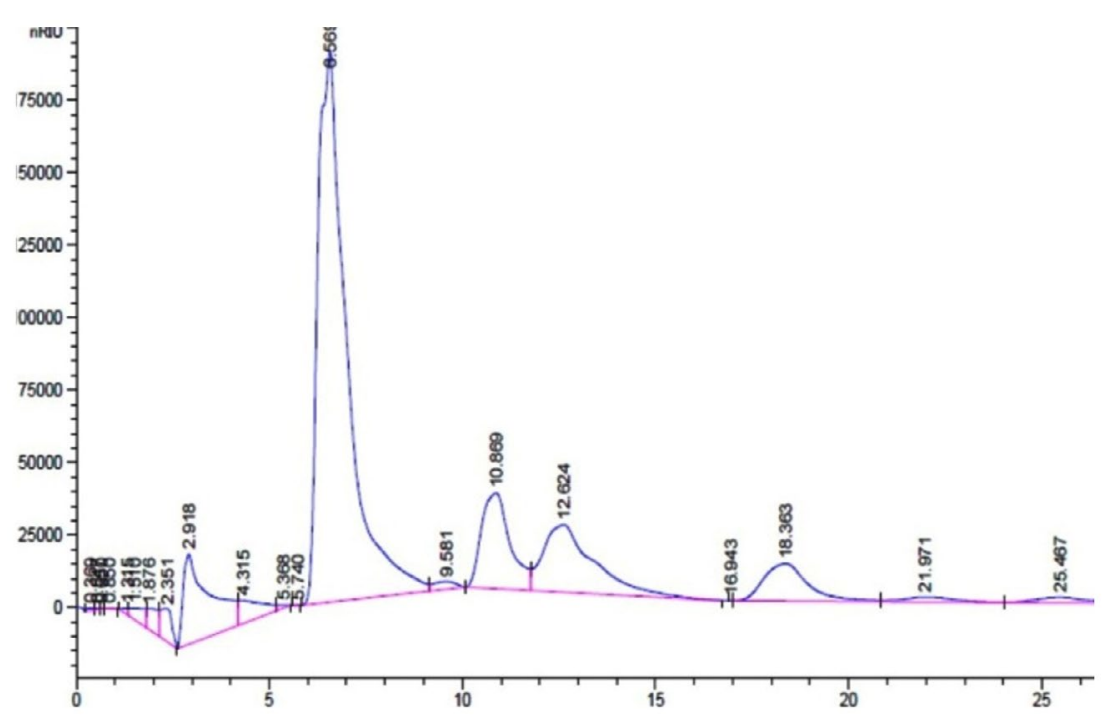

Fig. 6. L. fermentum with retention factor- Galactose and Glucose 2.931, Lactose 6.56, disaccharides 10.83 and 12.68 , trisaccharides 16.95 and 18.36 and tetrasaccharides 21.9 and 25.46 .

\%) and chloroform for L. plantarum cells which produced high $\beta$-gal have been previously reported (Gobinath and Prapulla, 2014). Thus $50 \mu \mathrm{l} \mathrm{SDS}$ and $50 \mu \mathrm{l}$ chloroform was found to be optimum for $\beta$-gal activity.

Availability of ONPG in abundance is required to achieve linearity of Miller assay for determining $\beta$-gal activity. $10 \mathrm{mg} / \mathrm{ml}$ ONPG concentration was found to be optimum for the activity. Gobinath et al., found similar effects with $10 \mathrm{mg} / \mathrm{ml}$ ONPG concentration produced high activity giving a yield of $3015 \mathrm{u} / \mathrm{ml}$ of $\beta$-gal enzyme (Gobinath and Prapulla, 2014).

Optimisation regarding temperature were observed by previously (Hsu et al., 2005, Gobinath et al., 2014, Li et al., 2020) where $\beta$-gal synthesis was stable at 40 to $45^{\circ} \mathrm{C}$, however, $35^{\circ} \mathrm{C}$ was found to be optimum for $L$. fermentum and above $50^{\circ} \mathrm{C}$ there was a rapid decrease in enzyme synthesis as well for the growth of the organism due to thermostability of enzyme (Cho et al., 2003; Rao and Dutta, 1977). $\beta$-gal production was prominent in the range 5.5 to $7.0(p<0.05)$ as reported by others (Gobinath and Prapulla, 2014). The results of our study with regard to $\mathrm{pH}$ are in agreement with previous reports who found similar results with Bifidobacterium longum CCRC 15708 and Streptococcus thermophilus (strain I) respectively for pH studies (Rao and Dutta, 1977; Hsu et al.,
2006).

Microorganisms utilize different carbon sources depending on the enzyme they produce. Carbon plays major function in the production of $\beta$-gal enzymes (Inchaurrondo et al., 1998). The enzyme synthesis was increased when $L$. fermentum was grown on galactose which shows the inducible nature of the enzyme. A similar observation was made by Kim and Rajagopal, who studied different carbon sources including glucose, lactose and maltose in MRS medium, for L. crispatus ATCC 33820 where galactose showed high $\beta$-gal activity, lactose showed moderate activity and glucose and maltose showed significant activity for $\beta$-gal production (Kim and Rajagopal, 2000). Gobinath et al., reported similar results for $\beta$-gal production in L. plantarum and highest activity was reported in medium containing galactose, followed by lactose. Similar results with $B$. animalis $\mathrm{Bb} 12$ and $L$. delbrueckiissp. bulgaricus ATCC 11842 produced higher $(p<0.05) \beta$-gal in galactose $(73.66$ $\mathrm{u} / \mathrm{mL}$ and $48.63 \mathrm{u} / \mathrm{mL}$ ) than lactose $(57.04 \mathrm{u} /$ $\mathrm{mL}, 33.0 \mathrm{u} / \mathrm{mL})$ and glucose $(31.08 \mathrm{u} / \mathrm{mL}, 28.9$ $\mathrm{u} / \mathrm{mL})$ and increase $(p<0.05)$ in $\beta$-gal production was observed in both the organisms $B$. animalis Bb12and L. delbrueckii ssp. bulgaricus ATCC 11842 after $12 \mathrm{hr}$ of incubation in galactose, lactose and glucose respectively (Prasad et al., 2013).

Garrido et al., investigated the utilization 
of commercial GOS by B. infantis ATCC 15697 and found that mono, disaccharides and DP3 of GOS was consumed to a great extent than higher oligosaccharides and the production of these oligosaccharides were confirmed by TLC (Garrido et al., 2013). Primary analysis products were formed from lactose, D-glucose and D-galactose along with di tri and tetra saccharides as a consequence of transgalactosylation reaction catalysed by $\beta$-gal enzyme. Transgalactosylation efficiency of permeabilized L. fermentum, confirmed further using HPLC, using $30 \%(\mathrm{w} / \mathrm{v})$ lactose as substrate, which a yielded $20 \%(w / v)$ of GOS at $18 \mathrm{hr}$ of reaction resulting about $65 \%$ of lactose conversion (Fig. 5 and 6). Other researcher, Kittibunchakul et al., (2020) also obtained DP2 and DP3 oligosaccharides as main component from Lactic acid bacteria and Bifidobacteria. The GOS mixture may be composed of mainly di, tri, and tetra saccharides, and considerably the conversion of lactose changes the yield and composition of GOS. Lactose breaks down into its monosaccharides as hydrolysis reaction increases and during transgalactosylation, di, tri and tetrasaccharides production may increase as a result of depletion of substrate and produced GOS acts as galactosyl acceptors resulting in formation of higher oligosaccharides. Chanalia et al., (2018) have observed similar band pattern in TLC with more than one band in the same lane indicating the presence of mixture different kind of GOS. Similar results were obtained by Song et al., (2013) from $30 \%$ whey medium, $30^{\circ} \mathrm{C}$ at $8 \mathrm{hr}$ of incubation obtained 19. $41 \%(\mathrm{w} / \mathrm{v})$ GOS and Liu et al., (2011) synthesized $37 \%$ of GOS at $45^{\circ} \mathrm{C}$ with $40 \%$ lactose at $9 \mathrm{~h}$ using $L$. fermentum $\mathrm{K} 4$ by cloning two genes coding for $\beta$-gal (Lac M and Lac L) expression in E.coli. The production of GOS and its higher structures will be further confirmed by ESI-MS studies.

In view of the greater efficiency of $\beta$-gal utilization, optimization of the relevant experimental conditions and parameters were studied including $\mathrm{pH}$ of the medium (7.0), temperature $\left(37^{\circ} \mathrm{C}\right)$, concentration of the permeabilizing agent (50:50), concentration of ONPG $(10 \mathrm{mg} / \mathrm{ml})$ and reaction time (two minutes) produced $6,232.127 \mathrm{u} / \mathrm{ml}$ of $\beta$-gal enzyme activity. The concentration of protein obtained from the isolated potential strain L. fermentum MT468249 was found to be $0.18529 \mathrm{mg} / \mathrm{ml}$.

\section{CONCLUSION}

The demand for prebiotic GOS is growing in the upcoming year and consumers are attracted towards functional foods having high nutritional value and gut health maintenance. The present study communicates $L$. fermentum to be a potential culture for the production of $\beta$-gal with relatively high specific activity. Permeabilization was achieved using SDS and chloroform which resulted in $6,232.13 \mathrm{u} / \mathrm{ml}$ of enzyme activity and maximum activity at $\mathrm{pH} 7.0$ and $35^{\circ} \mathrm{C}$ of temperature. Knowledge about the different parameters of the enzymes and production of prebiotic GOS thus can serve as the source for applications in the food and dairy industry. Studies regarding the optimization of GOS to obtain high yield are under investigation. Prebiotic GOS are functional food ingredients has the potential for enhancing food supplements for human consumption and prebiotic GOS are valuable in the production of possible health benefits.

\section{ACKNOWLEDGMENTS}

Authors are grateful to Director, DFRL, Mysore, for providing the necessary facilities to carry out this work.

\section{CONFLICT OF INTEREST}

The authors declare that there is no conflict of interest.

\section{AUTHORS' CONTRIBUTION}

All authors designed the experiments. SM has conducted the experiment. RB has analyzed the data and MMP and HVB have edited the manuscript. All authors read and approved the manuscript.

\section{FUNDING}

None.

\section{DATA AVAILABILITY}

All datasets generated or analyzed during this study are included in the manuscript

\section{ETHICS STATEMENT}

This article does not contain any studies with human participants or animals performed by 
any of the authors.

\section{REFERENCES}

1. Aachary AA, Prapulla SG. Corn-Cob induced endo-1, 4- $\beta$-D xylanase of Aspergillus oryzae MTCC 5154: production and characterization of xylobiose from glucuronoxylan. J Agric Food Chem. 2008;56:3981-3988. doi: 10.1021/ jf073430i

2. Barberis S, Gentina JC. Research note: Effect of dissolved oxygen level on lactase production by Kluyveromyces fragilis. Journal of Chemical Technology and Biotechnology, 1998;73:71-73. doi: 10.1002/(SICI)10974660(199809)73:1<71::AID-JCTB924>3.0.CO;2-D

3. Becerra M, Cerdan E, Siso MIG. Heterologous Kluyveromyces lactis beta-galactosidase production and release by Saccharomyces cerevisiae osmoticremedial thermosensitive autolytic mutants. Biochimica Biophysica Acta. 1997;1335:235-241. doi: 10.1016/ S0304-4165(97)00048-2

4. Chanalia P, Gandhi D, Attri P, Dhanda S. Purification and characterization of $\beta$-galactosidase from probiotic Pediococcus acidilactici and its use in milk lactose hydrolysis and galactooligosaccharide synthesis. Bioorganic chemistry. 2018;77:176-189. doi: 10.1016/j. bioorg.2018.01.006

5. Chen W, Chen H, Xia Y, Zhao J, Tian F, Zhang H. Production, purification, and characterization of a potential thermostable galactosidase for milk lactose hydrolysis from Bacillus stearothermophilus. Journal of Dairy Science. 2008;91:1751-1758. doi: 10.3168/ jds.2007-617

6. Cho YJ, Shin HJ, Bucke C. Purification and biochemical properties of a galactooligosaccharide producing beta-galactosidase from Bullera singularis. Biotechnol Lett. 2003;25:2107-2111. doi: 10.1023/B:BILE.0000007077.58019.bb

7. Davani-Davari D, Negahdaripour M, Karimzadeh I, et al., Prebiotics: Definition, Types, Sources, Mechanisms, and Clinical Applications. Foods. 2019;8:92. doi: 10.3390/ foods8030092

8. Dafam DG, Nuhu H, Ohemu TL, Olotu PN, Kagaru DC, Abubakar MS. Pharmacognostic Studies and Chromatographic Analysis of the Gum of Anacardium occidentale L (Anacardiaceae). Journal of Applied Pharmaceutical Science. 2014;4:61-63

9. Garrido D, Ruiz-Moyano S, Jimenez-Espinoza R, Eom HJ, Block DE, Mills DA. Utilization of galactooligosaccharides by Bifidobacterium longum subsp. infantis isolates. Food Microbiology. 2013;33:262-270. doi: 10.1016/j. fm.2012.10.003

10. Giacomini A, Corich V, Ollero FJ, Squartini A, Nuti MP. Experimental conditions may affect reproducibility of the $\beta$-galactosidase assay. FEMS Microbiology Letters. 1992;100:87-90. doi: 10.1016/0378-1097(92)90193-R

11. Gobinath D, Prapulla SG. Permeabilized probiotic Lactobacillus plantarum as a source of $\beta$-galactosidase for the synthesis of prebiotic galactooligosaccharides. Biotechnol Lett. 2014;36:153-157. doi: 10.1007/s10529013-1345-9

12. Goulas A, Tzortzis G, Gibson GR. Development of a process for the production and purification of $\alpha$-and $\beta$-galactooligosaccharides from Bifidobacterium bifidum NCIMB 41171. International Dairy Journal. 2007;17:648656.doi: 10.1016/j.idairyj.2006.08.010

13. Guerrero C, Vera C, Conejeros R, Illanes A. Transgalactosylation and hydrolytic activities of commercial preparations of $\beta$-galactosidase for the synthesis of prebiotic carbohydrates. Enzyme Microb Technol. 2015;70:9-17. doi: 10.1016/j. enzmictec.2014.12.006

14. Gupte AM, Nair JS. $\beta$-galactosidase production and ethanol fermentation from whey using Kluyveromyces marxianus NCIM 3551

15. Gupte AM, Enzyme and cell technology for bioremediation, Ph.D thesis, Bhabha Atomic Research Center, Mumbai, India, 2001.

16. Hirano $Y$, Tsumuraya $Y$, Hashimoto $Y$. Characterization of spinach leaf $\alpha$-l-arabinofuranosidases and $\beta$ galactosidases and their synergistic action on an endogenous arabinogalactan-protein. Physiologia Plantarum. 1994;92:286-296. doi: 10.1111/j.13993054.1994.tb05339.x

17. Hsu CA, Yu RC, Chou CC. Purification and characterization of a sodium-stimulated $\beta$-galactosidase from Bifidobacterium longum CCRC 15708. World J Microbiol Biotechnol. 2006;22:355-361. doi: 10.1007/s11274-0059041-0

18. Inchaurrondo VA, Flores MV, Voget CE. Growth and $\beta$-galactosidase synthesis in aerobic chemostat cultures of Kluyveromyces lactis. J Ind Microbiol Biotechnol. 1998;20:291-298.doi: 10.1038/sj.jim.2900526

19. Intanon M, Arreola SL, Pham NH, Kneifel W, Haltrich D, Nguyen TH. Nature and biosynthesis of galactooligosaccharides related to oligosaccharides in human breast milk. FEMS Microbiology Letters. 2014;353:89-97. doi: 10.1111/1574-6968.12407

20. Jeong KJ, Park IY, Kim MS, Kim SC. High-level expression of an endoxylanase gene from Bacillus sp. in Bacillus subtilis DB104 for the production of xylobiose from xylan. Applied Microbiology and Biotechnology. 1998;50:113-118. doi: 10.1007/s002530051264

21. Kim JW, Rajagopal S.N. Isolation and characterization of $\beta$-galactosidase from Lactobacillus crispatus. Folia Microbiologica. 2000;45:29-34. doi: 10.1007/BF02817446

22. Li W, Zhao X, Zou S, Ma Y, Zhang K, Zhang M. Scanning assay of $\beta$-galactosidase activity. Appl Biochem Biotechnol,. 2012;48:603-607. doi: 10.1134/S0003683812060075

23. Li D, Li S, Wu Y, et al., Cloning and Characterization of a New $\beta$-Galactosidase from Alteromonas sp. QD01 and its potential in synthesis of Galacto-Oligosaccharides. Marine Drugs. 2020;18:312. doi: 10.3390/md18060312

24. Liu GX, Kong J, Lu WW, et al., $\beta$-Galactosidase with transgalactosylation activity from Lactobacillus fermentum K4. Journal of Dairy Science. 2011;94:58115820. doi: 10.3168/jds.2011-4479

25. Mahoney RR, Nickerson TA, Whitaker JR. Selection of strain, growth conditions, and extraction procedures for optimum production of lactase from Kluyveromyces fragilis. Journal of Dairy Science.1975;58:1620-1629. doi: 10.3168/jds.S0022-0302(75)84760-6

26. Mahoney R.R. Galactosyl-oligosaccharide formation during lactose hydrolysis: a review. Food chemistry, 1998; 63:147-154 
doi: 10.1016/S0308-8146(98)00020-X

27. Marwaha SS, Kennedy JF. Whey-pollution problem and potential utilization. Int J Food Sci Tech. 1988;23:323-336. doi: 10.1111/j.1365-2621.1988.tb00586.x

28. Miller JH. Assay of B-galactosidase In: Experiments in molecular genetics. Cold Spring Harbor Laboratory, Cold Spring Harbor, N.Y. 1972.

29. Nguyen $\mathrm{TH}$, Splechtna B, Steinbock M, et al., Purification and characterization of two novel $\beta$-galactosidases from Lactobacillus reuteri. J Agric Food Chem. 2006 ;54: 49894998. doi: 10.1021/jf053126u

30. Nguyen TH, Splechtna B, Krasteva $S$, et al., Characterization and molecular cloning of a heterodimeric $\beta$-galactosidase from the probiotic strain Lactobacillus acidophilus R22. FEMS Microbiology Letters. 2007;269:136-144. doi: 10.1111/j.1574-6968.2006.00614.x

31. Panesar R, Panesar PS, Singh RS, Kennedy JF, Bera MB. Production of lactose-hydrolyzed milk using ethanol permeabilized yeast cells. Food Chem. 2007;101:786-790. doi: 10.1016/j.foodchem.2006.02.064

32. Prasad LN, Ghosh BC, Sherkat F, Shah NP. Extraction and characterisation of $\beta$-galactosidase produced by Bifidobacterium animalis, 2013:487-94

33. Rao MV, Dutta SM. Production of beta-galactosidase from Streptococcus thermophilus grown in whey. Appl Environ Microbiol. 1977;34:185-188. doi: 10.1128/AEM.34.2.185188.1977

34. Sangwan V, Tomar SK, Singh RR, Singh AK, Ali B. Galactooligosaccharides: novel components of designer foods. J Food Sci. 2011;76:R103-111. doi: 10.1111/j.1750- 3841.2011.02131.x

35. Slavin J. Fiber and prebiotics: mechanisms and health benefits. Nutrients. 2013;5:1417-1435. doi: 10.3390/ nu5041417

36. Somkuti GA, Dominiecki ME, Steinberg $D H$. Permeabilization of Streptococcus thermophilus and Lactobacillus delbrueckii subsp. bulgaricus with ethanol. Current Microbiology. 1998;36:202-206. doi: 10.1007/ s002849900294

37. Song TL, Kang K, Yoo S, Lee S, Yoon SS. Synthesis of Galactooligosaccharides in the Cheese Wheybased Medium by a Lactase from Lactobacillus paracasei YSM0308. Korean Journal for Food Science of Animal Resources. 2013;33:565-571. doi: 10.5851/ kosfa.2013.33.5.565

38. Sriphannam W, Lumyong $S$, Niumsap $P$, Ashida $H$, Yamamoto $\mathrm{K}$, Khanongnuch $\mathrm{C}$. A selected probiotic strain of Lactobacillus fermentum CM33 isolated from breast-fed infants as a potential source of $\beta$-galactosidase for prebiotic oligosaccharide synthesis. The Journal of Microbiology. 2012;50:119-126. doi: 10.1007/s12275012-1108-7

39. Kittibunchakul S, van Leeuwen S. S, Dijkhuizen L, Haltrich D, Nguyen TH. Structural comparison of different Galactooligosaccharide mixtures formed by $\beta$-Galactosidases from Lactic acid bacteria and bifidobacteria. J Agric Food Chem. 2020;15:4437-4446. doi: 10.1021/acs. jafc.9b08156 